\title{
Right to health in Russian Federation: identification of its current stage of constitutional and legal recognition
}

\author{
Reconhecimento constitucional e legal do \\ direito à saúde na Rússia: cenário atual
}

Elena Tarasenko*

\begin{abstract}
Russian Federation has made a strong legal commitment to the human right to health through the ratification of several key international human rights laws. Current public health care policies also demonstrate that Russian Federation has committed itself to provide the human right to health protection of people residing with its jurisdiction. All residents of Russia are eligible for medical care free of charge. Medical services are provided directly to patients by government health care providers. This includes general and specialist medical care, hospitalization, diagnostic laboratory services, dental care, maternity care and transportation, free drugs for disabled, medical rehabilitation, etc. The legal basis for the human right to health at the federal level is provided by a variety of legislative acts (codes, federal laws), presidential decrees, decisions and proposals of the government of the Russian Federation, and orders of the government and of the Ministry of Health and other ministries. The legal basis at the regional level is provided by legislative instruments enacted by the governments of the Subjects of Russian Federation.
\end{abstract}

Keywords: Right to Health; Russian's Federal Law 323; Russia Federation; Russian Public Health System.

\section{RESUMO}

A Rússia mantém um forte compromisso legal com o direito humano à saúde, por meio da ratificação de diversos tratados internacionais de direitos humanos fundamentais. As

* Postgraduated, Institute of Sociology, Russian Academy of Sciences. Associate Professor, Department of Health Care Administration and Economy, Faculty of Public Administration, Higher School of Economics. Moscow - Russia. E-mail: elenatar05@mail.ru

Paper received: 12/15/2013. Reviewed: 1/6/2014. Approved: 1/23/2014. 
políticas públicas de saúde atuais também demonstram que o país vem se empenhando para garantir a efetivação do direito humano à saúde de sua população. Todos os residentes do território russo são elegíveis para atendimento médico gratuito. Os serviços médicos são prestados diretamente aos pacientes por instituições governamentais e incluem clínica geral e especialidades médicas, hospitalização, serviços laboratoriais de diagnóstico, assistência odontológica, assistência à maternidade, transporte, medicamentos gratuitos para pessoas com deficiência, reabilitação médica etc. A base jurídica para o direito humano à saúde no nível federal está fundamentada em uma série de atos legislativos (códigos e leis federais), decretos presidenciais, atos e resoluções do governo federal, do Ministério da Saúde e de outros ministérios. Em nível regional, a base jurídica fundamenta-se por instrumentos legislativos decretados pelos governos locais e unidades federativas russas. ${ }^{(1)}$

Palavras-chave: Direito à Saúde; Federação Russa; Lei Federal Russa 323; Sistema Nacional de Saúde Russo.

\section{Introduction}

The human right to health means that every man has the right to the highest achievable norm of physical and mental health, which includes access to all medical services, sanitation, adequate food and water, decent housing, healthy working conditions, and a clean environment. The human right to health also means that medical clinics, hospitals, drugs, physician' services must be available, accessible, acceptable, and of good quality for every person, on an equitable basis, where and when needed.(1) The model of a health care system must be guided by the key human rights standards and principles, established in international legal documents. This paper aims to present how Russian Federation recognizes the right to health in its legal framework and what kind of legal guarantees exists to the fulfillment of the right to health.

Russian Federation has made a strong legal commitment to the human right to health through the ratification of several key international human rights laws. Current public health care policies also demonstrate that Russian Federation has committed itself to provide the human right to health protection of people residing with its jurisdiction.

All residents of Russia are eligible for medical care free of charge. Medical services are provided directly to patients by government health care providers. This includes general and specialist medical care, hospitalization, diagnostic laboratory services, dental care, maternity care and transportation, free drugs for disabled, medical rehabilitation, etc.

\footnotetext{
${ }^{1}$ DAVIES, Sara E. Global politics of health. Cambridge: Polity Press, 2009. p.62-63.
} 
The legal basis for the human right to health at the federal level is provided by a variety of legislative acts, such as federal laws, presidential decrees, decisions and proposals of the government of the Russian federation, and orders of the government and of the Ministry of Health and other ministries. The legal basis at the regional level is provided by legislative instruments enacted by the governments of the Subjects of Russian Federation.

\section{Legal framework}

Russia's current Constitution of 12 December $1993^{(2)}$ adopted the principle of the separation of the power between executive, legislative, and judicial branches. Russian courts are split into three separate court systems: the Constitutional Court of the Russian Federation, Courts of General Jurisdiction and the Arbitrazh (commercial). The Office of the Procurator General (prosecutor) is the body in charge of state prosecution in courts. ${ }^{(3)}$

The Constitution of the Russian Federation contains two articles related to the right to health and Russian healthcare system: Articles 7 and 41.

Article 7:

1. The Russian Federation is a social state whose policy is aimed at creating conditions for a worthy life and a free development of man.

2. In the Russian Federation the labor and health of people shall be protected, a guaranteed minimum wages and salaries shall be established, state support ensured to the family, maternity, paternity and childhood, to disabled persons and the elderly, the system of social services developed, state pensions, allowances and other social security guarantees shall be established.

Article 41 of the Russian Constitution translates the right to public health into the national legal system. It is important to say that the article 41.1. ensures the right to health of each citizen. "Everyone shall have the right to health protection and medical aid. Medical aid in state and municipal health establishments shall be rendered to individuals gratis, at the expense of the corresponding budget, insurance contributions and other proceeds."

Article 41.2 determines financial resources of the right to health of Russian citizens:

In the Russian Federation federal programmes for protecting and improving the health of the population shall be financed by the

\footnotetext{
2 RUSSIA. Constitution of the Russian Federation. Available at: <http://constitution.garant.ru/english>. Accessed in: January $19^{\text {th }} 2014$.

${ }^{3}$ SVENDSEN, K.; BULNIK, I. A brief overview of the Russian Legal System. Brussels, Belgium: EU-Russia Legal Cooperation, 2010. Available at: <http://isn.ethz.ch/Digital-Library/Publications/ Detail/?lng=en\&id=117085>. Accessed in: Dec. $23^{\text {rd }} 2013$.
} 
State; measures shall be adopted to develop state, municipal and private health services; activities shall be promoted which facilitate the improvement of health, the development of physical culture and sport, ecological and sanitary-epidemiological well-being.

Article 41.3 promises that "The concealment by officials of facts and circumstances posing a threat to the life and health of people shall entail responsibility according to federal law."

So the main Russian law inherited the guarantee of free medical care to people. It is also very important to stress that it stipulated equal rights of public and private healthcare which is sometimes missing in other legislation acts.

Also there are other federal laws witch protect health welfare of Russian citizens: FL-323 "On the fundamentals of health protection in the Russian Federation" (2011); FL-326 "On mandatory health insurance in the Russian Federation" (2010); FL-55 "Sanitary and epidemiological welfare of the population" (1999); FL-328 "On prevention of spread of disease caused by HIV in the Russian Federation" (1995); FL-3 "On narcotic and psychotropic substances" (1998); FL -61 "On circulation of medicines" (2010); FL-3125-1 "On mental health care and guarantees for citizens' rights when delivering It" (1992); FL- 125 "On the donation of blood and blood components" (2012); FL-96 "On atmospheric air protection" (1999); FL-157 "On immunological prevention of infectious diseases" (1998); FL-77 "On prevention of TB spread in the Russian Federation" (2001); FL-87 "On limitations of tobacco smoking" (2001); FL-181 "On the social protection of persons with disabilities in the Russian Federation" (1995).

The other key legal documents approved by Russian Federal Government are: National Priority Project on Health 2007-2012; Federal Target Program Development of the Pharmaceutical and Medical Industry of the Russian Federation for the period up to 2020 and Beyond (Federal Government Decree n. 91); Federal State Program of Pharmacological Support of Patients with 7 Expensive Diseases ("7 Nosologies", from 2008) and the Concept of Demographic Policy of the Russian Federation to the year 2025 (Presidential Decree n. 1351, October 9, 2007). Also now Russian society is discussing the draft of a Federal Law "On Protection of Public Health from the Effects of Tobacco Usage" which would ban smoking in public areas and remove smoking areas from institutions, hospitals and cafés.

\section{Federal Law 323 (2011)}

The Federal Law "On The Fundamentals of Health Protection in the Russian Federation" (FL-323, 2011) sets the legal foundations for the national health care system to assure the right of all citizens to health protection, accessible and quality health care and drug provision.

The main principles of the national health care system include the following axes: priority of preventive medicine; accessible and free-of-charge guaranteed volume 
of medical and pharmaceutical services; differentiated approach to medical and pharmaceutical service provision based on demands of the population; priority of sanitary-epidemiological well-being assurance and disease prevention measures; priority of medical and pharmaceutical services for children and mothers; continuity of care at all levels of health care delivery; inter-regional cooperation and coordination in the field of public health protection; unification of: certification, licensing and accreditation of medical and pharmaceutical practice; training and re-training medical and pharmaceutical professionals; medical and pharmaceutical development of standard techniques; vital and health statistics and statistical reporting procedures; subordination of medical and pharmaceutical professionals to health administration agencies; public participation in health protection and health administration decision-making.

Its article 2 offers some definitions of health and health protection. According to this legal instrument, health is a state of physical, mental and social well being with the absence of disease disorders of the organs and systems of the body. Article 2 also establishes that public health protection is a system of political, economic, legal, social, scientific, health, including sanitary and anti-epidemic (preventive), the nature undertaken by state authorities of the Russian Federation, bodies of state power of Subjects of the Russian Federation, local self-government institutions, officials and other persons, citizens, in order to prevent disease, preserving and strengthening the physical and mental health of everyone, keep it long and active life, providing it with care.

According to Article 4 of this Federal Law, the national health policy is based on the following principles:

1. State support to measures designed for public health maintenance and improvement;

2. recognition of public health as a critical national security factor;

3. observance of the constitutional human and citizen rights in the area of health protection, providing each individual with guaranteed medical and pharmaceutical services in accordance with Federal program of state commitments with respect to health care provision (state commitments program) and federal health care quality standards;

4. allocation of adequate financial resources to the health care system and the state commitments program;

5. delineation of responsibilities and jurisdiction in the area of health administration between the Russian Federation, the Subjects of the Russian Federation, and the agencies of local self-government, with the recognition of integrity of personal, regional and national interests regarding public health; responsibility of the agencies of state authority of the Russian Federation and relevant health officials for ensuring citizens rights regarding health protection; 
6. juridical and physical persons' economic interest in public health protection;

7. assurance of accessibility and affordability of medical, pharmaceutical and medico-social care for all citizens; social justice in exercising legal citizens rights in the field of health protection regardless of social and health status, place of residence, level of personal income and other circumstances;

8. social protection of citizens in the event of disability;

9. coordination of interaction and co-subordination of the federal agencies of executive authority, agencies of executive authority of the Subjects of the Russian Federation, agencies of local self-government in the area of public health to ensure the principles of accessibility and justice in health care provision throughout the country;

10. priority of disease prevention measures; healthier life style promotion;

11. equal opportunities of health institutions to develop regardless of their ownership and what agency they report to;

12. State support to scientific research in the area of diagnostics and treatment;

13. State support to health promoting initiatives and activities in the Russian Federation;

14. promotion of international multi- and bilateral cooperation in the area of health protection.

It is important remark that Russian citizens must be responsible to maintain their health. For example, Article 27 (FL-323) "Responsibilities of citizens in health" notes that citizens in the cases stipulated by the Russian Federation are required to undergo medical examinations. Also citizens suffering from diseases which are dangerous to others, in cases stipulated by the legislation of the Russian Federation, are required to undergo a medical examination and treatment as well as in the prevention of these diseases. And patients who are hospitalized must comply with the treatment regimen, including at a certain period of temporary disability and with the hospital rules.

Article 5 of the FL-323, "The rights of citizens in the field of occupational health and safety and their State guarantees", promises that:

1. Health interventions should be based on the recognition, observance and protection of human rights and in accordance with the generally recognized principles and norms of international law.

2. The State provides health care to citizens regardless of gender, race, age, nationality, language, disease presence, condition, origin, property and official status, place of residence, attitude to religion, convictions, membership of public associations and other circumstances. 
3. The State guarantees citizens protection from all forms of discrimination arising from the any disease presence.

The State recognizes the health of children as a fundamental condition for physical and mental development of children (Article 7 "Priority to the protection of children's health").

The Article 12 of the Federal Law 323 highlights that the priority of prevention in health care is provided by:

1. the development and implementation of a healthy lifestyle, including programs to reduce tobacco and alcohol consumption, prevention and control of non-medical use of narcotic drugs and psychotropic substances;

2. the implementation of anti-epidemic (preventive) measures;

3. the implementation of measures for the prevention and early detection of diseases, including the prevention of socially significant diseases and their control;

4. preventive and other medical examinations, clinical examinations, follow-up in accordance with the legislation of the Russian Federation;

5. implementation of measures to preserve the life and health of citizens in their study and work in accordance with the legislation of the Russian Federation.

Article 45 of the Law 323 prohibits euthanasia of patients, following the legislation of other European countries like Portugal and Greece. ${ }^{(4)}$ According to the law, "euthanasia means the acceleration at the request of the patient's death by any action (or inaction) or facilities, including the cessation of artificial measures to maintain the patient's life".

Finally, to complete the legal framework presentation, it is stated in Russian normative statutes that each major woman of a childbearing age has the right to artificial fertilization and implantation of an embryo. Artificial fertilization of a woman and implantation of an embryo are carried out in establishments that have been licensed for that, upon getting a written consent of spouses.

\section{The different guarantees and juridical strategies used by Russia to fulfill the right to health effectiveness}

Once recognized the right to health in Russian's Constitution, it is important to notice that the implementation of social rights is a complex path. The right to health effectiveness depends in part on normative political arguments about

\footnotetext{
${ }^{4}$ AUMONIER, N.; BEIGNIER, B.; LETELLIER, P. L'euthanasie. Paris: Presses Universitaires de France, 2012.
} 
which institutions of the State should have interpretive authority over defining our human right to health. It also requires information about how judicial and other institutions will respond to the demands of constitutional right to health recognition, and about whether they can and will conform to the expectations of the theory put forward. ${ }^{(5)}$

In Russia, the main guarantees are being settled first by specific laws on right to health. These laws give to courts the possibility to act in the effectiveness of the right to health. Nevertheless, the main strategy so far has been the creation of laws and the implementations of public policies by the executive. This topic will present some of the main programs and policies defined by law that have been put in place in Russia.

In 2006 a national priority project on health was launched to improve the Russian healthcare system through improved funding and healthcare infrastructure. Named as The National Priority Project on Health 2007-2012, one of its main targets was the development of preventive outpatient primary care in Russia, trying to incorporate in the country several international standards created for ameliorating the health care, focusing in primary care ${ }^{(6)}$ and intersectoral actions. ${ }^{(7)}$

The project also included others targets such as the increase in accessibility, improvement of the quality of specialized, advanced and high-technological health care, advancement of medical care for mothers and children and promotion of a healthy lifestyle.

The project also collaborated to hospitals and clinics to acquire advanced, highend equipment and ambulances and to build new medical centers. Through this project, it was instituted nation-wide vaccination programs and free health check up. It has also contributed to develop a medical technology market through initiatives to combine healthcare and information technology. One of its focuses was increasing the salary of health professionals who work in the primary care as well as expand their training programs.

This project was mostly financed by the federal budget. However regional and municipal levels have also contributed a lot to the financing of the program. In 2006 the budget of the program was 78,98 billion RUR, while the total budget for 2007-2009 was 346,3 billion RUR.

Other important program put in place in Russia was entitled Concept for Demographic Policy of the Russian Federation up to 2025. It proposes several measures for improvement of accessibility and quality of free medical care to

\footnotetext{
${ }^{5}$ KING, J. Judging social rights. Cambridge: University Press, 2012. p.13.

${ }^{6}$ SOLAR, O.; IRWIN, A. A conceptual framework for action on the social determinants of health: discussion paper for the commission on social determinants of health, WHO, Geneva, 2007.

7 SHANKARDASS, K.; SOLAR, O.; MURPHY, K.; GREAVES, L.; O'CAMPO, P. A scoping review of intersectorial action for health equity involving governments. International Journal of Public Health, v. 57, p.25-33, 2012.
} 
women. These include development of family-oriented prenatal technologies, equipment improvements at obstetric facilities and development of high-technology medical care to women.

Russian Federation has ratified the Convention on the Rights of the Child, ${ }^{(8)}$ therefore it has committed itself to respect to its items. Special measures used by Russia to the effectuation of the children' right to health are included in the Plan of Action for Improving Children's Situation in the Russian Federation for the Period 1998-2000, the presidential program "Children of Russia" and in the special federal program "Children of the North". A special federal program "Healthy Child" was operating during 2002-2006. Besides that the National Priority Project Health contains the sub-program Improvement of Medical Care to Mothers and Children.

Child immunization is carried out in accordance with a special national inoculation scheme. Injections against viral hepatitis and rubella, as well as re-vaccination against parotitis were introduced in 1997. The constantly high level of child immunization has brought about an elimination of poliomyelitis and a reduction in the cases of diphtheria, measles, whooping cough and parotitis.

The Federal Law on the "Social Protection of Persons with Disabilities in the Russian Federation" (1995) provides a range of rights of disabled people, including the right for medical care and free medication (every year Russian Ministry of Health claims special list of unpaid medical drugs for disabled people). There is an explicit concern reflected in national policy regarding access of disabled persons to social protection and employment.

Prevention and elimination of tuberculosis in Russian Federation is secured trough legal and policy measures, including a Federal Law "On the prevention of the spread of tuberculosis in the Russian Federation" (2001) and a federal program "Urgent Measures to Tackle Tuberculosis in Russia for the Period 19982004". To prevent children from contracting the most serious forms of the disease, newborn babies are vaccinated against this disease.

The Federal Law "On prevention of the spread of HIV infection in the Russian Federation" was adopted in 1995, setting up an epidemiological monitoring system to track the spread of HIV and a system to monitor the safety of donated blood, organs and tissue. Within the framework of the campaign Rational people, rational choices young people were informed about how to avoid HIV/Aids and sexually transmitted infections. In response to this rapidly escalating problem, the Russian Government has made several efforts to combat the growing prevalence of HIV/Aids among its citizens, particularly since 2005. Several government-sponsored entities, such as the Government Commission on HIV/Aids, which was established in 2006, have been working to develop HIV/Aids programs and review existing legislation and regulations pertaining to treatment of the disease.

\footnotetext{
${ }^{8}$ UNICEF. Convention on the Rights of the Child. Available at: <http://www.unicef.org/crc/>.
} 
These programs and others have had some measurable success in acting to make treatment for HIV/Aids more available and widespread.

In order to ensure the constitutional rights for citizens of the Russian Federation to receive free medical care the government of the Russian Federation approves a Guarantee Package of Medical Services every year. Some free services must be covered by government budgets, such as: urgent medical care; ambulatory, polyclinic and hospital care provided to patients with socially significant diseases (skin and venereal diseases, tuberculosis, Aids, mental problems, drug addiction, pregnancy and delivery abnormalities; some types of conditions of children and infants; dispensaries monitoring healthy children; specialized pharmaceutical care and prostheses; some types of expensive medical care.

The free services to be covered by the mandatory medical insurance funds are ambulatory, polyclinic and hospital care provided to patients with: contagious and parasitic diseases, excluding venereal diseases; tuberculosis and Aids; cancer, endocrine system diseases, skin diseases; nutrition abnormalities, nervous system diseases; blood diseases, immune system pathology, heart and circulatory diseases; eye, ear and respiratory diseases; digestive system pathology, all types of injuries and poisonings; bone and muscle diseases; some types of inborn adult pathology and some other diseases.

The definition of health care costs per person (per capita indexes) is in charge of regional authorities, using federally determined methodology.

There are also services which are explicitly excluded from the guaranteed package: cosmetic surgery; homeopathic, alternative, or 'non-professional' therapies offered by practitioners with no medical qualification; dental services except basic provision for children, veterans and other special groups; medical prostheses including dentures (except for veterans and other special groups); rehabilitation or convalescence in institutions other than those approved by the Ministry of Health; educational activities and health promotion literature from non-Ministry of Health approved health centers training in emergency procedures and nursing; pharmaceuticals for outpatients.

Compulsory medical insurance system has become important and necessary part of healthcare. Compulsory medical insurance system is a form of social protection of the population, providing equal rights of Russian Federation citizens on receiving available qualified medical care. Since January $1^{\text {st }} 2011$, citizens have got the right to choose a primary care doctor and an insurance company within the mandatory health insurance system. The Federal Fund for Mandatory Medical Insurance is responsible for implementing the government's policy of mandatory medical insurance as part of the state system of social insurance. Primary objectives of the Federal fund for compulsory medical insurance include: providing implementation of the Federal Law 326 "On Mandatory Health Insurance in the Russian Federation" (2010); ensuring statutory citizens rights in the compulsory medical insurance system; generality of compulsory medical 
insurance; achievement of social justice and equality of citizens; assurance of financial stability of the compulsory medical insurance system. Compulsory medical insurance system is addressed to enforcement of Russian Federation citizens constitutional rights on free medical and pharmaceutical care in the state and public health facilities in the extent, consistent with the Program of state guarantees for delivering free medical care to Russian Federation citizens.

Regulation on labour relations in the healthcare field, according to the Constitution of the Russian Federation, is provided by the labour legislation (including work safety legislation), consisting of the Labour Code, other federal orders and the laws of subjects of the Russian Federation. The issues of working environment, medical waste management etc. are regulated by the Labour Code, Manual of the Ministry of Health on Hygienic Criteria for Evaluation and Classification of Labour Conditions, Federal Law "On Production and Consumption Wastes", Federal Law "On Technical Regulations" and other legal acts at the federal and regional level.

Also each region has its own regional health care legislation. The regions must ensure compliance with federal programs, in particular those focused on the control of conditions and infectious diseases defined as being of high social priority.

\section{The federative issue and right to health effectiveness}

To better present the federative issue related to right to health effectiveness, this topic will give a zoom at the Regional Legislation in Saint Petersburg. Such as to other countries organized in federative models, like Brazil, ${ }^{(9)}$ Russian federative organization has an important impact to the country health system.

The basic law in Saint Petersburg is the law "On the Health Protection of the Citizens of Saint Petersburg". It contains the main priorities of the healthcare development according to the federal legislation and in particular it stipulates the competences of the executive and legislative authorities.

Legislative Assembly of the city has the following competences in health protection of citizens:

1. to pass laws and other legal acts, including: the main directions of the city policy to health protection of the citizens; approval of special healthcare programs; tax exemption, fees and other payments for organizations whose activities are aimed at protecting the health of citizens in Saint Petersburg;

2. to provide control functions to ensure compliance with the laws and with the city's budget, to finance public health, including: the budget of Saint Petersburg for free pharmacological supply, budget implementation of the

\footnotetext{
9 PAIM, J.;TRAVASSOS, C.; ALMEIDA, C.; BAHIA, L.; MACINKO, J. The Brazilian health system: history, advances and challenges. Lancet, v. 377, n. 9779, p.1778-1797, 2011.
} 
Territorial Medical Insurance Fund of Saint Petersburg; compliance with the city laws and other legal acts adopted by the Legislative Assembly regarding environmental protection, environmental safety and sanitary-epidemiological welfare of population.

The competences of the executive bodies of Saint Petersburg (the government) in health protection of the citizens are: to develop and implement city policies on health protection of citizens; to form a government public healthcare system; to ensure the development and logistical support for the public healthcare institutions and social protection institutions; to ensure and monitor the quality of healthcare; coordinate the activities of public healthcare institutions; assist development of municipal healthcare organizations; develop special programs in the field of health protection; to provide information on the health situation of the city, measures taken for its protection and prevalence of socially significant diseases and diseases that pose a danger to others; to organize and to coordinate activities of the state educational institutions, providing staff medical training; to organize the education of the citizens in the field of health; to organize international cooperation in the field of health protection of citizens.

It is important to say that a number of factors indicate the need for measures to improve the situation in the field of the human right to health and public health care, improving the regulatory framework for the industry. This requires a more precise, specific delineation of jurisdiction and powers between the Federation and its subjects, as well as clarification of the powers of the Federation.

\section{How Russian Federation treats the rare diseases}

The way countries treats the rare diseases varies around the world, and two important references on that can be found in United States ${ }^{(10)}$ and in Europe. ${ }^{(11)}$ In Russia, the government's attention to the needs of patients with rare diseases has started to take shape recently.

As in other countries, the term "orphan disease" has been used for a long time, but has not been legislated, being partially replaced with the other, often lengthy definitions such as "limited number of patients with rare and/or the particularly severe pathology." In Russia, no criteria for classifying a disease like this one

\footnotetext{
${ }^{\circ}$ UNITED STATES FOOD AND DRUG ADMINISTRATION. The Orphan Drug Act (as amended) Code of Federal Regulations, Title 21, Revised as of April 1, 2004. Silver Spring, MD, USA: FDA, 2012. Available at: <http://www.fda.gov/Regulatorylnformation/Legislation/ FederalFoodDrugandCosmeticActFDCAct/SignificantAmendmentstotheFDCAct/OrphanDrugAct/ default.htm>. Accessed in: June $1^{\text {st }} 2012$.

${ }^{11}$ EUROPEAN UNION COMMITTEE OF EXPERTS ON RARE DISEASES. 2012 Report on the State of the Art Of Rare Disease Activities in Europe of the European Union Committee of Experts on Rare Diseases. Paris: EUCERD; 2012. Available at: <http://www.eucerd.eu/upload/file/ Reports/2012ReportStateofArt RDActivitiesIV.pdf>. Accessed in: Feb. $12^{\text {th }} 2013$.
} 
has been envisaged by Federal Law 61 "On the turnover of Medicines" (2011) and by the subordinate legislation adopted in its pursuance.

Russian healthcare system is being reformed now. As seen, the Federal Law 323 was adopted in 2011 and it has presented, for the first time in the history of Russia, a special chapter devoted to rare diseases. According to its article 44: "Rare (orphan) diseases are those diseases which have prevalence no more than 10 cases on 100,000 population." As a result, since January 2012, orphan diseases has been recognized as diseases that account for up to 10 cases per 100,000 people. The list of such diseases is determined by the Ministry of Health on the basis of statistics and posted on its official website.

Russian authorities have singled out three categories of diseases as priorities: socially-important diseases; diseases which pose a danger to others and rare (orphan) diseases. Regarding rare diseases, Russia has set 3 categories of them:

3. diseases included in the Federal Program of Pharmacological Support to Patients with Seven Expensive Diseases ("7 Nosologies"): hemophilia; cystic fibrosis; pituitary nanism; Gaucher's disease; myeloid leukemia and other hemoblastosis; multiple sclerosis: and conditions after organ and (or) tissue transplantation;

4. rare (orphan) diseases (the list of orphan diseases is defined by the federal executive authority body on the basis of statistical data);

5. life-threatening acute and chronic progressing rare (orphan) diseases leading to shortening of life or disability of citizen (article 44). (The list of this kind of diseases is approved by the government.)

The law establishes rules for the public funding of orphan disease treatment. Funds to purchase medicine for the treatment of malignant neoplasms of lymphoid and of the "7 Nosologies" are allocated from the federal budget. The treatment of all other orphan diseases is subsidized from the budgets of the constituent entities of the Russian Federation.

Both the new law and the rare disease list are significant steps towards improving access to the treatment for rare disease patients. Rare Disease Day 2012 is the beginning of the whole rare disease year in Russia. It was an initiative of Russian organizations of patients with rare diseases, such as the National Association of Organizations of Patients with Rare Diseases "Genetics", that was supported by Russian Ministry of Health.

As part of this effort, the Ministry of Health is developing a federal registry of patients with rare diseases and orphan drugs to be reimbursed by the state and overseen by regional authorities. For the purposes of supplying drugs to people suffering from rare diseases, a register is maintained of people suffering from life-threatening, acute and chronic, progressive, and rare (orphan) diseases that shorten life expectancy or cause disability. 


\section{Society participation in Russia's public health State's decisions}

Russia's constitution provides basic rights with regard to the right to health protection and medical care. There are a number of rights which are reasonably well defined in other relevant pieces of legislation, as showed in this paper. It is important to remember the example of the Protection of Citizens health law (no. 5487, 22 July 1993) establishes a number of patient rights including choice of physician, right to a second opinion and informed consent ${ }^{(12)}$.

A plethora of patient organisations exists in Russia, offering a variety of programmes and services. Examples of groups include Aids Infoshare, Moscow Cancer Society and the All-Russian Public Organisation of Disabled People with Multiple Sclerosis. The empowerment and participation of patient's and civil society in Russia's State's Decisions are actually based in two special platforms for dialogue and participation in state structures, gathering public authorities, social organizations and patients interests. ${ }^{(13)}$

Specifically, the Federal Law "On public chamber and decree on the procedure for establishing councils attached to federal ministries, agencies, and services" (2005) established two health policy advisory councils on which patients and patients groups have places reserved. The councils are attached respectively to the Ministry of Health and Rospotrebnadzor (the federal consumer rights protection and human wellbeing surveillance service) and they have competence to make policy recommendations, however, these recommendations are advisory and non-binding on the respective agency.

As advisory bodies, the councils carry out preliminary considerations and work on some questions like: improvement of quality and availability of medical care (including medicinal maintenance); efficiency and safety of medical technologies and medical production; reforming of system of public health services; upgrading of the state system; rendering of the medical and social care.

The councils have the function to develop proposals to the Ministry of Health, concerning the right to health protection and to social care. They also discuss projects about the accepted standard legal certificates that regulate the relations in the sphere of public health services and social development. With its activities, the councils promote the right to health protection, having the power to create, if necessary, expert groups to solve questions assigned to it.

\footnotetext{
${ }^{12}$ POPOVICH, Larisa; POTAPCHIK, Elena; SHISHKIN, Sergey; RICHARDSON, Erica; VACROUX, Alexandra; MATHIVET, Benoit. Russian Federation. Health system review. Health Systems in Transition, v.13, n.7, p.175-177, 2011.

${ }^{13}$ STOCKHOLM Network Research Team. Patient Power: What it takes for patient associations to help shape public policy. Stockholm Network, 2013. Available at: <http://www.stockholm-network. org/downloads/publications/Patient_Power_Final_1.pdf>. Accessed in: Dec. 2013.
} 


\section{Final considerations}

Recent progresses in health policies, including the substantive increase in funding, indicate that the Russian government takes active steps towards the effectiveness of the human right to health for its citizens. For assessing of the current stage of the human right to health in the Russian Federation, it is possible to use the "AAAQ" framework (Availability, Accessibility, Acceptability and Quality $)^{15}$ set out in the General Comment 14 as a good methodological device.

The availability of the right to health care seems to be adequately fulfilled in Russia. Health care services and facilities are usually sufficiently available for Russian citizens in terms of quantity. The Russian health system has always had the worlds' highest numbers of hospital beds and doctors. Current policy measures also focus on the increase in number of the high-tech clinics and facilities. The geographical accessibility of health services seems to be satisfactory in urban areas. However, there are problems with the accessibility in rural areas.

The biggest challenges in terms of the human right to health in Russian Federation stay on the relative dimensions of quality and affordability of health care. As official standards of quality of free medical care are not established or known, the services are sometimes inadequate. Corruption also influences negatively the affordability of health care.

Despite the fact that free medical care is a constitutional guarantee, in reality, sometimes patients pay personnel "under the table" fees for doctors to obtain the medical treatment of adequate standard. Some patients prefer to pay for private health care which according to public opinion are of a higher level of quality.

Access to free health care is banned for persons without registration of their address in the passport and they have to pay for all the medical services.

It is important to distinguish one theoretical problem related to the right to health. This problem is the weak methodological development of the theoretical term "right to health". This term is absent from the government's public health policy lexicon. In Russia the expression "right to health" changed into the "right to health care" in public health policy discourse.

\section{References}

AUMONIER, N.; BEIGNIER, B.; LETELLIER, P. L'euthanasie. Paris: Presses Universitaires de France, 2012.

DAVIES, Sara E. Global politics of health. Cambridge: Polity Press, 2009. 
EUROPEAN UNION COMMITTEE OF EXPERTS ON RARE DISEASES. 2012 Report on the State of the Art Of Rare Disease Activities in Europe of the European Union Committee of Experts on Rare Diseases. Paris: EUCERD;2012. Available at: <http://www.eucerd.eu/upload/file/Reports/2012ReportStateofArt RDActivitiesIV.pdf>. Accessed in: Feb. $12^{\text {th }} 2013$.

KING, J. Judging social rights. Cambridge: University Press, 2012.

PAIM, J.;TRAVASSOS, C.; ALMEIDA, C.; BAHIA, L.; MACINKO, J. The Brazilian health system: history, advances and challenges. Lancet, v. 377, n. 9779, p.1778-1797, 2011.

POPOVICH, Larisa; POTAPCHIK, Elena; SHISHKIN, Sergey; RICHARDSON, Erica; VACROUX, Alexandra; MATHIVET, Benoit. Russian Federation. Health system review. Health Systems in Transition, v.13, n.7, p.175-177, 2011.

SOLAR, O.; IRWIN, A. A conceptual framework for action on the social determinants of health: discussion paper for the commission on social determinants of health, WHO, Geneva, 2007.

SHANKARDASS, K.; SOLAR, O.; MURPHY, K.; GREAVES, L.; O'CAMPO, P. A scoping review of intersectorial action for health equity involving governments. International Journal of Public Health, v. 57, p.25-33, 2012.

STOCKHOLM Network Research Team. Patient Power: What it takes for patient associations to help shape public policy. Stockholm Network, 2013. Available at: <http://www.stockholm-network.org/downloads/publications/Patient_Power_ Final_1.pdf>. Accessed in: Dec. 2013.

SVENDSEN, K.; BULNIK, I. A brief overview of the Russian Legal System. Brussels, Belgium: EU-Russia Legal Cooperation, 2010. Available at: <http://isn.ethz.ch/ Digital-Library/Publications/Detail/?Ing=en\&id=117085>. Accessed in: Dec. $23^{\text {rd }} 2013$.

UNITED STATES FOOD AND DRUG ADMINISTRATION. The Orphan Drug Act (as amended) Code of Federal Regulations, Title 21, Revised as of April 1, 2004. Silver Spring, MD, USA: FDA, 2012. Available at: <http://www.fda.gov/ RegulatoryInformation/Legislation/FederalFoodDrugandCosmeticActFDCAct/ SignificantAmendmentstotheFDCAct/OrphanDrugAct/default.htm>. Accessed in: June $1^{\text {st }} 2012$.

\section{Acknowledgments}

I would like to thanks Professor Fernando Aith (Faculdade de Medicina, Universidade de Sao Paulo), for his help in editing this manuscript. 